OPEN ACCESS

Edited by:

Bellamkonda K. Kishore, University of Utah Health,

United States

Reviewed by:

Michael Winder,

University of Gothenburg, Sweden

Willmann Liang,

The Chinese University of Hong Kong,

China

*Correspondence:

Christian Moro

cmoro@bond.edu.au

Specialty section:

This article was submitted to Integrative Physiology, a section of the journal

Frontiers in Physiology

Received: 26 November 2019

Accepted: 28 May 2020

Published: 23 June 2020

Citation:

Stromberga Z, Chess-Williams $R$ and Moro C (2020) Prostaglandin E2

and F2alpha Modulate Urinary

Bladder Urothelium, Lamina Propria

and Detrusor Contractility via the FP

Receptor. Front. Physiol. 11:705

doi: 10.3389/fphys.2020.00705

\section{Prostaglandin E2 and F2alpha Modulate Urinary Bladder Urothelium, Lamina Propria and Detrusor Contractility via the FP Receptor}

\section{Zane Stromberga, Russ Chess-Williams and Christian Moro* \\ Centre for Urology Research, Faculty of Health Sciences \& Medicine, Bond University, Gold Coast, QLD, Australia}

Current pharmacological treatment options for many bladder contractile dysfunctions are not suitable for all patients, thereby bringing interest to the investigation of therapies that target a combination of receptors. This study aimed to compare responses of $\mathrm{PGE}_{2}$ on the urinary bladder urothelium with lamina propria (U\&LP, also called the bladder mucosa) or detrusor smooth muscle and attempt to identify the receptor subtypes mediating $\mathrm{PGE}_{2}$ contractile responses in these tissues. In the presence of selective EP1 - 4 receptor antagonists, varying concentrations of $\mathrm{PGE}_{2}$ were applied to isolated strips of porcine U\&LP and detrusor that were mounted in organ baths filled with Krebsbicarbonate solution and gassed with carbogen. The addition of $\mathrm{PGE}_{2}(1$ and $10 \mu \mathrm{M})$ and $\mathrm{PGF}_{2 \alpha}(10 \mu \mathrm{M})$ to U\&LP preparations caused significant increases in the baseline tension and in the spontaneous phasic contractile frequency. In detrusor preparations, significant increases in the baseline tension were observed in response to $\mathrm{PGE}_{2}$ ( 1 and $10 \mu \mathrm{M})$ and $\mathrm{PGF}_{2 \alpha}(10 \mu \mathrm{M})$, and spontaneous phasic contractions were initiated in $83 \%$ of preparations. None of the selective $\mathrm{PGE}_{2}$ receptor antagonists inhibited the increases in baseline tension in both U\&LP and detrusor. However, the antagonism of $\mathrm{PGF}_{2 \alpha}$ receptor showed significantly inhibited contractile responses in both layers of the bladder. This study presents prostaglandin receptor systems as a potential regulator of urinary bladder contractility. The main contractile effects of PGE 2 in both U\&LP and detrusor are mediated via the FP receptor with no observed contribution from any of the four EP receptors.

Keywords: inflammatory mediators, prostaglandins, prostaglandin antagonists, urinary bladder, overactive bladder, bladder inflammation, urothelium, mucosa

Abbreviations: $\mathrm{ATP}$, adenosine triphosphate; $\mathrm{OAB}$, overactive bladder; $\mathrm{PGE}_{2}$, prostaglandin $\mathrm{E}_{2} ; \mathrm{PGF}_{2 \alpha}$, prostaglandin $\mathrm{F}_{2 \alpha}$; SEM, standard error of the mean; U\&LP, lamina propria with urothelium; UAB, underactive bladder; $\alpha \beta \mathrm{m}-\mathrm{ATP}$, $\alpha, \beta-$ methylene ATP. 


\section{INTRODUCTION}

Bladder contractile dysfunctions, such as overactive bladder (OAB) and underactive bladder (UAB), are common lower urinary tract dysfunctions that lower the overall quality of life in people living with it (Haylen et al., 2010; D'ancona et al., 2019), heightens the likelihood of developing depression and anxiety, as well as increase healthcare usage (Milsom et al., 2012). Despite extensive research investigating the mechanisms that potentially mediate bladder contractions, the cause and development of many lower urinary tract dysfunctions are poorly understood. Bladder contractions are under the control of the parasympathetic nervous system (De Groat et al., 1981) and mediated by the release of acetylcholine that acts upon the M2 and M3 muscarinic receptors found in the detrusor smooth muscle (Hegde et al., 1997; Sigala et al., 2002). It has been recognized that the urothelium, which lines the lumen of the bladder, is capable of responding to mechanical, chemical and thermal stimuli (Birder, 2006; Stromberga et al., 2019, 2020b). Furthermore, it is capable of releasing several signaling molecules in response to stretch, including acetylcholine (Moro et al., 2011) ATP and nitric oxide (Ferguson et al., 1997; Fry and Vahabi, 2016) that are involved in the modulation of the micturition reflex. Myofibroblasts (also referred to as interstitial cells) found in the underlying lamina propria are thought to be involved in modulating bladder behavior by amplifying sensory responses to stretch occurring during the filling phase (Fry et al., 2007). Therefore, the involvement of the urothelium and the underlying lamina propria should be considered as potential contributors to bladder contractile pathology.

Prostaglandins have been suggested to be involved in the modulation of bladder function for decades. They are synthesized from arachidonic acid that is released from the cell membrane via the hydrolysis of the SN-2 bond by the phospholipase A2 enzyme (PLA2) (Clark et al., 1991). Prostaglandins can also be produced locally within the U\&LP and smooth muscle layers in the human urinary bladder (Abrams et al., 1979; Jeremy et al., 1987). Two cyclooxygenase isoforms COX-1 and COX-2 metabolize arachidonic acid into $\mathrm{PGH}_{2}$, which is subsequently converted into five primary prostaglandins via their respective synthases: $\mathrm{PGE}_{2}, \mathrm{PGD}_{2}, \mathrm{PGF}_{2} \alpha, \mathrm{PGI}_{2}$ and $\mathrm{TXA}_{2}$ (Woodward et al., 2011). These signaling molecules exert their function through the stimulation of nine specific G-protein coupled receptors (GPCRs): EP1-EP4, DP1, DP2, FP2, IP, and TP, respectively. Both COX-1 and COX-2 are expressed within the bladder wall (De Jongh, 2007, 2009) specifically on the urothelium, lamina propria and on the surface of the inner muscle bundles of the detrusor. COX-1 is predominately expressed in the basal and intermediate layers of the urothelium and on the interstitial cells located in the lamina propria, indicating that these cells are capable of respond to prostaglandins (De Jongh, 2009). The production of prostaglandins differs between species. For example, in the rat bladder, $\mathrm{PGI}_{2}$ is the major prostaglandin produced (Jeremy et al., 1984), whereas in the rabbit bladder it is $\mathrm{PGE}_{2}$ (Leslie et al., 1984). In the human bladder, the primary prostaglandins synthesized are $\mathrm{PGI}_{2}$, followed by $\mathrm{PGE}_{2}, \mathrm{PGF}_{2 \alpha}$, and $\mathrm{TXA}_{2}$ (Jeremy et al., 1984; Masunaga et al., 2006). However, there are significant differences in the bladder contractile responses between species for the different prostaglandin receptor subtypes (Root et al., 2015).

Studies involving human detrusor have shown that the release of prostaglandins has direct influences on the micturition reflex (Bultitude et al., 1976; Andersson et al., 1977). Overproduction of prostaglandins have been observed in several conditions, including bladder outlet obstruction (Masick et al., 2001), bladder overactivity due to spinal cord injury (Masunaga et al., 2006), and in inflammation (Wheeler et al., 2001). Furthermore, contractions of the detrusor smooth muscle in response to acetylcholine and ATP are enhanced by prostaglandins in both rabbit (Anderson, 1982) and guinea-pig animal models (Nile et al., 2010). There are complex interactions between the three chemicals, as ATP enhances $\mathrm{PGE}_{2}$ release via a P2purinoreceptor-mediated mechanism (Kasakov and Vlaskovska, 1985), and acetylcholine is a modulator of $\mathrm{PGE}_{2}$ release (Nile and Gillespie, 2012). The interactions between these mediators can potentially result in amplification of molecule signaling and therefore in increased contractile activity, further supporting the interest in investigating prostaglandin involvement in contractile disorders such as OAB. Other research has also shown interest in prostaglandin release from the lower urinary tract. For example, the presence of $\mathrm{PGE}_{2}$ in the urine has been linked to bladder dysfunction and proposed as a potential future biomarker (Reyes and Klahr, 1990). To further this, urine samples collected from female patients with overactive bladder showed that there were significant increases in the $\mathrm{PGE}_{2}$ and $\mathrm{PGF}_{2 \alpha}$ levels when compared with the control group (Kim et al., 2006).

Prostaglandin $E_{2}$, in particular, is thought to be the most likely contributor to bladder disorders as it can modulate bladder function via afferent signaling (Andersson, 2010) and potentially detrusor overactivity by sensitizing capsaicin-sensitive afferent nerve endings (Maggi, 1988; Park et al., 1999). It is released upon degranulation of mast cells (Schmauder-Chock and Chock, 1989) together with histamine, which is also capable of impacting the bladder contractility (Stromberga et al., 2019, 2020a). Moreover, $\mathrm{PGE}_{2}$ is produced locally in the bladder in response to distension and inflammation (Funk, 2001). Notably, the excitatory effects exerted on the bladder wall via the stimulation of $\mathrm{PGE}_{2}$ receptors has previously been studied in the rat (Chuang et al., 2012) and mouse (Schroder et al., 2004; Mccafferty et al., 2008) animal models. There are four identified prostaglandin $\mathrm{E}_{2}$ receptor subtypes: $\mathrm{EP} 1, \mathrm{EP} 2, \mathrm{EP} 3$, and EP4. The presence of the EP1 and EP2 receptor subtypes has been shown in guinea pig urothelium and lamina propria (Rahnama'i et al., 2010) and the expression of all four $\mathrm{PGE}_{2}$ receptor subtypes (EP1-EP4) has been identified in the canine bladder using in situ hybridization and immunohistochemistry (Ponglowhapan et al., 2010). Generally, activation of EP1 and EP3 receptors is associated with an excitatory response, whereas EP2 and EP4 are associated with inhibition of smooth muscle contractility (Woodward et al., 2011). Furthermore, clinical uses of the prostaglandin $\mathrm{E}_{2}$ agonist dinoprostone, include the stimulation of uterine smooth muscle contractions during labor (Stephenson and Wing, 2015) with the prostaglandin $\mathrm{F}_{2 \alpha}$ agonist, carboprost, being a viable alternative to oxytocin during the management of labor (Sunil Kumar et al., 2016). Therefore, the involvement 
of EP1, EP3 and FP receptors is of particular interest in the modulation of lower urinary tract contractility due to their excitatory effect when stimulated.

Alterations in bladder physiology in disease states has been thought to primarily occur through the regulation of detrusor smooth muscle contractility. However, it is increasingly recognized that the bladder urothelium with lamina propria (U\&LP, also called the bladder mucosa) plays an important role in the overall contractility of the bladder and in its intracellular signaling. As such, recent research has focused on the effects of pharmacological mediators on the physiology of the U\&LP and the detrusor as separate layers. This study aimed to compare responses of the urothelium with lamina propria to $\mathrm{PGE}_{2}$ with those of the detrusor and identify the receptor subtypes responsible for the $\mathrm{PGE}_{2}$-mediated contractions in these tissues.

\section{MATERIALS AND METHODS}

\section{Tissue Preparation}

Urinary bladders were obtained from female Large-WhiteLandrace pigs (approximately 6 months old, with a live-weight of $80-100 \mathrm{~kg}$ ) from the local abattoir after slaughter for the routine commercial provision of food. Isolated strips $(10 \mathrm{~mm} \times 5 \mathrm{~mm})$ of porcine bladder were removed from the anterior wall of the bladder dome region and urothelium with lamina propria (U\&LP) carefully dissected from the underlying detrusor layer. Two adjacent strips were taken from each animal's bladder and paired together as control-experimental tissues, with each paired strip preparation expressed as " $n$ " where comparisons or changes are recorded. $n$ equates to the number of individual bladders used in this study.

Strips of U\&LP and detrusor tissue were suspended in $10 \mathrm{~mL}$ organ baths (Labglass, Brisbane, QLD, Australia) containing Krebs-bicarbonate solution ( $\mathrm{NaCl} 118.4 \mathrm{mM}, \mathrm{NaHCO}_{3} 24.9 \mathrm{mM}$, $\mathrm{CaCl}_{2} 1.9 \mathrm{mM}, \mathrm{MgSO}_{4} 2.41 \mathrm{mM}, \mathrm{KCl} 4.6 \mathrm{mM}, \mathrm{KH}_{2} \mathrm{PO}_{4} 1.18 \mathrm{mM}$, and $\mathrm{D}$-glucose $11.7 \mathrm{mM}$ ) at $37^{\circ} \mathrm{C}$ and perfused with a gas mixture of $95 \%$ oxygen and $5 \%$ carbon dioxide. The preparations were washed three times with Krebs-bicarbonate solution and tension adjusted to approximately $2 \mathrm{~g}$, which then became the tissue baseline. A single dose of agonist was added to the U\&LP and detrusor preparations after an incubation period with an antagonist or vehicle control. The concentrations specific for each receptor subtype were determined using affinity values appearing in the literature utilizing similar methodology and isolated tissue bath experiments. Tissue strips exposed to antagonists or vehicle controls were incubated for $30 \mathrm{~min}$ to allow full equilibration with the receptor. Each experiment was completed within $20 \mathrm{~min}$ after the addition of the agonist. Baseline tension, frequency and amplitude of spontaneous phasic contractions were recorded simultaneously using isometric force transducers (MCT050/D, ADInstruments, Castle Hill, NSW, Australia) on a PowerLab system using LabChart v7 software (ADInstruments). Porcine urinary bladders are a well-recognized animal model for bladder research (Cheng et al., 2011; Parsons et al., 2012; Mitsui et al., 2019; Stromberga et al., 2019) with similar physiology and pharmacology to human bladders. As no animals were bred, harmed, culled, interfered, or interacted with as part of this research project, Animal Ethics Approval was not required for bladder use (Queensland Government, 2016).

\section{Pharmaceutical Agents}

Prostaglandin $\mathrm{E}_{2}, \mathrm{~F}_{2 \alpha}$, EP1 receptor antagonist SC-19220, EP1, and EP2 receptor antagonist AH6809, EP3 receptor antagonist L-798106, EP4 receptor antagonist AH23848, FP receptor antagonist AL-8810 and ATP receptor agonist $\alpha, \beta$-methylene ATP were obtained from Cayman Chemicals, Ann Arbor, MI, United States. The muscarinic receptor antagonist atropine, cyclooxygenase (COX) inhibitor indomethacin, and the nitric oxide synthase inhibitor $\mathrm{N}_{\omega}$-Nitro-L-arginine were obtained from Sigma Aldrich, St. Louis, MO, United States. Prostaglandin $\mathrm{E}_{2}$, prostaglandin $\mathrm{F}_{2 \alpha}$, AH6809 and indomethacin were dissolved in $100 \%$ ethanol and diluted as needed with distilled $\mathrm{H}_{2} \mathrm{O}$. Atropine, $\mathrm{N}_{\omega}$-Nitro-L-arginine, and $\alpha, \beta$-methylene ATP were dissolved in distilled $\mathrm{H}_{2} \mathrm{O}$ and diluted as required. SC19220, L798196, AH23848, and AL-8810 were dissolved in DMSO and diluted with distilled $\mathrm{H}_{2} \mathrm{O}$.

\section{Experimental Procedure}

A single dose of prostaglandin $\mathrm{E}_{2}(1$ or $10 \mu \mathrm{M})$ or prostaglandin $\mathrm{F}_{2 \alpha}(10 \mu \mathrm{M})$ was applied to an isolated strip of U\&LP or detrusor after a 30-minute equilibration period with a selective receptor antagonist. Baseline tensions and the amplitude and frequency of spontaneous phasic contractions of U\&LP were measured before the application of the agonist and $5 \mathrm{~min}$ after addition. As spontaneous contractions were only observed in $21 \%$ of detrusor samples, only baseline tension was measured (before the application of the agonist, $10 \mathrm{~min}$ after and $20 \mathrm{~min}$ after).

\section{Measurements and Statistical Analysis}

The changes in the baseline tension were measured before the addition of an agonist and at the peak contractile response. The frequency of spontaneous contractions was measured over a period of $5 \mathrm{~min}$ and expressed as the number of spontaneous phasic contraction cycles per minute (cpm). The average amplitude was measured from base to peak of each spontaneous contraction. Measurements for frequency and amplitude were taken before any agonist was added and during the peak contractile response to the agonist. Data was graphed and analyzed using GraphPad Prism version 8.1.1 for Windows (GraphPad Software, La Jolla, CA, United States) and results shown as the mean change \pm SEM. Responses between control and experimental tissues were compared using a Student's $t$-test with $p<0.05$ considered significant.

\section{RESULTS}

\section{Prostaglandin $E_{2}$ on U\&LP Preparations}

In the absence of prostaglandin $\mathrm{E}_{2}$ or any receptor antagonists, strips of urothelium with lamina propria (U\&LP) exhibited spontaneous phasic contractions at frequencies of $3.34 \pm 0.06$ cycles per $\min ^{-1}(\mathrm{cpm})$ with amplitudes of $0.52 \pm 0.02 \mathrm{~g}(n=215$ for both). In response to prostaglandin $\mathrm{E}_{2}(1 \mu \mathrm{M})$, U\&LP baseline 
TABLE 1 | U\&LP effect of prostaglandin $E_{2}(1$ and $10 \mu \mathrm{M})$ on the baseline tension and on the frequency and amplitude of spontaneous phasic contractions (mean change \pm SEM).

\begin{tabular}{|c|c|c|c|c|}
\hline $\mathrm{PGE}_{2}$ conc. & $\Delta$ Tension (g) & $\Delta$ Frequency $(\mathrm{cpm})$ & $\Delta$ Amplitude (g) & $n$ \\
\hline $1 \mu \mathrm{M}$ & $1.01 \pm 0.08^{\star \star *}$ & $1.13 \pm 0.19^{\star \star \star}$ & $-0.14 \pm 0.04^{\star \star \star}$ & 38 \\
\hline $10 \mu \mathrm{M}$ & $1.36 \pm 0.09^{\star \star \star}$ & $1.19 \pm 0.30^{\star \star}$ & $-0.16 \pm 0.03^{\star \star}$ & 42 \\
\hline
\end{tabular}

tensions increased by $91 \pm 9 \%(n=38, p<0.001)$, the frequency of spontaneous phasic contractions increased by $39 \pm 7 \%(n=38$, $p<0.001)$ and amplitudes decreased by $18 \pm 5 \%(n=38$, $p<0.001$ ) during the peak response (Table $\mathbf{1}$ and Figure $\mathbf{1}$ ). The addition of an even higher concentration of prostaglandin $\mathrm{E}_{2}(10 \mu \mathrm{M})$ caused increases in the U\&LP baseline tensions by $106 \pm 9 \%(n=42, p<0.001)$, frequencies of spontaneous phasic contractions by $40 \pm 10 \%(n=42, p<0.01)$ and amplitude decreases by $28 \pm 6 \%(n=22, p<0.001)$ during peak response (Table 1 and Figure 1).

\section{Prostaglandin $E_{2}$ on Detrusor Preparations}

In detrusor preparations, $\mathrm{PGE}_{2}$ caused concentration-dependent increases in baseline tension over the increasing concentrations (1-10 $\mu \mathrm{M}$, Table 2 and Figure 2). Detrusor preparations did not reach a visible peak in response to $\mathrm{PGE}_{2}$ within the experimental timeframe, so each tension recording was completed at set intervals of 10 and $20 \mathrm{~min}$. In response to prostaglandin $\mathrm{E}_{2}$ ( $1 \mu \mathrm{M}$, Table 2 and Figure 2), an increase of $80 \pm 13 \%(n=38$, $p<0.001$ ) was observed $10 \mathrm{~min}$ after the addition of the agonist, and in response to prostaglandin $\mathrm{E}_{2}(10 \mu \mathrm{M}$, Table 2 and Figure 2) an increase of $155 \pm 21 \%(n=34, p<0.001)$ was observed $10 \mathrm{~min}$ after the addition of agonist. Twenty minutes after the addition of prostaglandin $\mathrm{E}_{2}(1 \mu \mathrm{M}$, Table 2$)$, baseline tensions had increased by $107 \pm 13 \%(n=38, p<0.001)$, whereas $20 \mathrm{~min}$ after the treatment with prostaglandin $\mathrm{E}_{2}(10 \mu \mathrm{M}$, Table 2), had increased by $175 \pm 21 \%(n=34, p<0.001)$.

Only $21 \%$ of all detrusor preparations exhibited spontaneous phasic contractions at baseline and as such, the frequency and amplitude of spontaneous activity was not calculated. Of
TABLE 2 | Detrusor effect of prostaglandin $E_{2}(1$ and $10 \mu \mathrm{M})$ on the baseline tension and on the frequency and amplitude of spontaneous phasic contractions (mean change \pm SEM).

\begin{tabular}{|c|c|c|c|}
\hline $\mathrm{PGE}_{2}$ conc. & $\Delta$ Tension $(\mathrm{g})$ at $10 \mathrm{~min}$ & $\Delta$ Tension $(\mathrm{g})$ at $20 \mathrm{~min}$ & $n$ \\
\hline $1 \mu \mathrm{M}$ & $0.77 \pm 0.09^{\star \star \star}$ & $1.06 \pm 0.09^{\star \star \star}$ & 38 \\
\hline $10 \mu \mathrm{M}$ & $1.34 \pm 0.14^{\star \star \star}$ & $1.46 \pm 0.11^{\star \star \star}$ & 34 \\
\hline
\end{tabular}

${ }^{* * *} p<0.001$. Paired Student's two-tailed t-test.

those that did not exhibit baseline activity, spontaneous phasic contractions were initiated after the addition of $\mathrm{PGE}_{2}$ in $83 \%$ of preparations.

\section{Receptor-Selective Antagonists in U\&LP Preparations}

The responses to prostaglandin $\mathrm{E}_{2}$ were observed in the presence of the selective receptor antagonists: SC-19220 (EP1 antagonist, $10 \mu \mathrm{M})$, AH6809 (EP1/EP2 antagonist, $10 \mu \mathrm{M})$, L-798106 (EP3 antagonist, $100 \mathrm{nM}$ ) and $\mathrm{AH} 23848$ (EP4 antagonist, $10 \mu \mathrm{M})$. None of the prostaglandin $\mathrm{E}_{2}$ receptor antagonists had any effect on baseline tension, frequency or amplitude of spontaneous phasic contractions and they also had no effect on U\&LP in response to prostaglandin $\mathrm{E}_{2}(1 \mu \mathrm{M}$, Table 3$)$. The time required to reach peak baseline tension was investigated in U\&LP tissues treated with $\mathrm{PGE}_{2}$ in the presence and absence of EP receptor antagonists. In response to prostaglandin $E_{2}(1 \mu M), U \& L P$ tissue strips took $4.48 \pm 0.28 \mathrm{~min}$ to reach their peak baseline tensions. Tissues incubated with SC-19220 ( $1 \mu \mathrm{M}, n=8, p<0.05)$ took $6.37 \pm 0.39 \mathrm{~min}$ to reach peak. There were no significant differences in times taken to reach peak baseline tension in tissues treated with either AH6809, L-798106 or AH23848.

The potential influence of receptor systems, other than prostaglandin $\mathrm{E}_{2}$, to contribute contractile responses to $\mathrm{PGE}_{2}$ were investigated. Neither the baseline tension, frequency nor amplitude of spontaneous phasic contractions in response to prostaglandin $\mathrm{E}_{2}(10 \mu \mathrm{M})$ were affected by the presence of the muscarinic receptor antagonist atropine $(1 \mu \mathrm{M})$, cyclooxygenase (COX) inhibitor indomethacin $(5 \mu \mathrm{M})$, nitric oxide synthase inhibitor $\mathrm{N}_{\omega}$-Nitro-L-arginine (L-NNA, $100 \mu \mathrm{M}$ ) or P2X receptor desensitizing agonist $\alpha, \beta$-methylene ATP ( $\alpha \beta$ m-ATP,
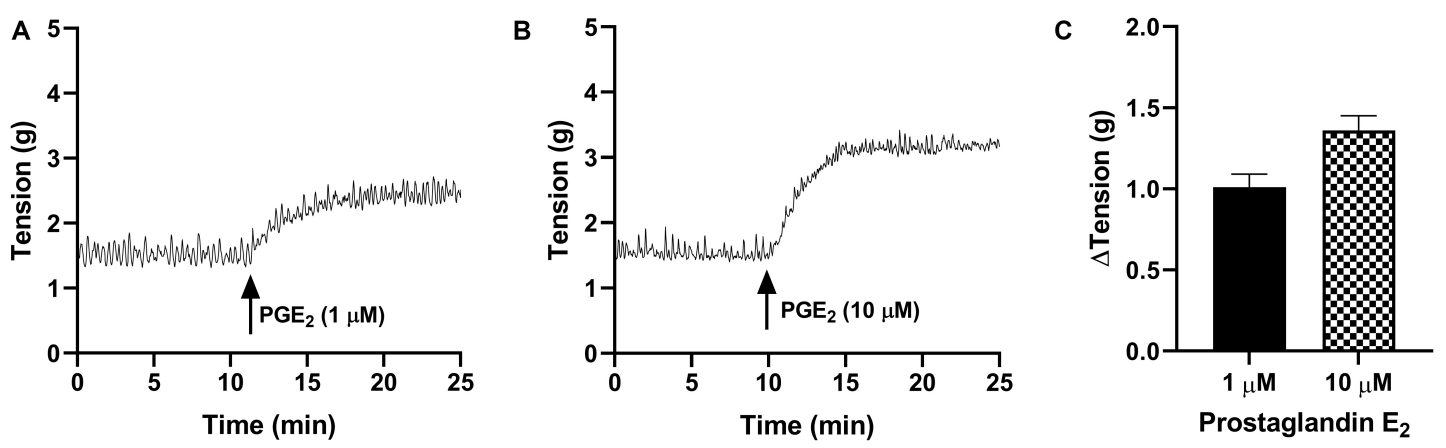

FIGURE 1 | Traces showing changes to baseline tension of U\&LP in response to PGE 2 at concentrations of $1 \mu \mathrm{M}$ (A) and $10 \mu \mathrm{M}$ (B) over 15 min. (C) Peak responses after the addition of $\mathrm{PGE}_{2}(1 \mu \mathrm{M}, n=38)$ and $\mathrm{PGE}_{2}(10 \mu \mathrm{M}, n=42)$. 

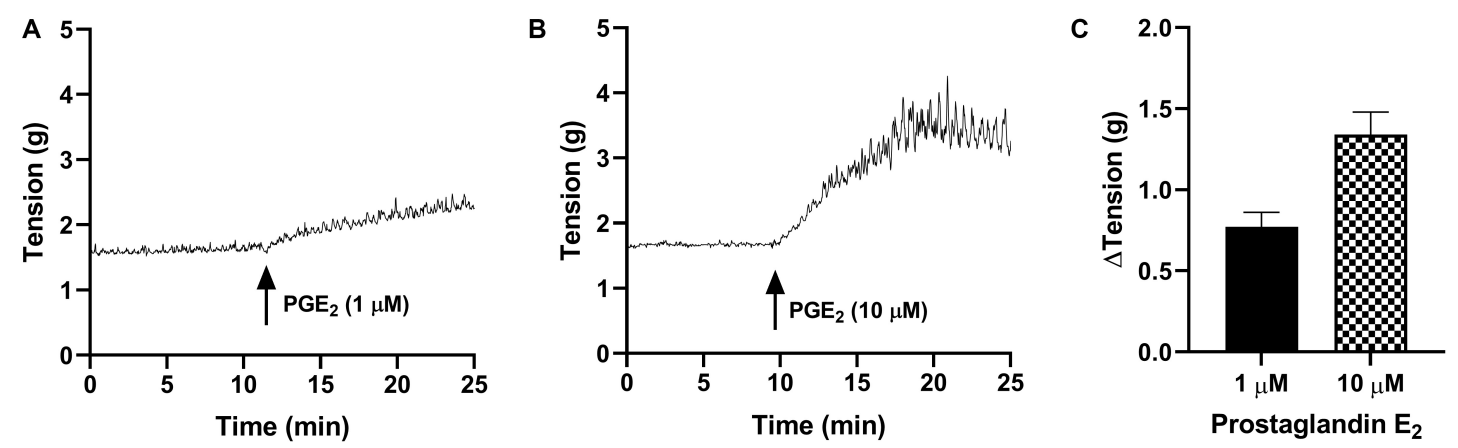

FIGURE 2 | Traces showing changes to baseline tension of detrusor smooth muscle in response to PGE 2 at concentrations of $1 \mu \mathrm{M}$ (A) and $10 \mu \mathrm{M}$ (B) over 15 min. (C) Peak responses after the addition of $\mathrm{PGE}_{2}(1 \mu \mathrm{M}, n=38)$ and $\mathrm{PGE}_{2}(10 \mu \mathrm{M}, n=34)$.

TABLE 3 | Baseline tension and phasic contraction responses to U\&LP treatment with prostaglandin $\mathrm{E}_{2}(1 \mu \mathrm{M})$ in the absence and presence of prostaglandin $\mathrm{E}_{2}$ receptor antagonists (mean change \pm SEM).

\begin{tabular}{|c|c|c|c|c|c|c|}
\hline \multirow[b]{2}{*}{ Antagonist } & \multirow[b]{2}{*}{ Conc. } & \multicolumn{2}{|c|}{$\Delta$ Tension (g) } & \multicolumn{2}{|c|}{$\Delta$ Frequency (cpm) } & \multirow[b]{2}{*}{$n$} \\
\hline & & Absence & Presence & Absence & Presence & \\
\hline SC-19220 & $10 \mu \mathrm{M}$ & $1.01 \pm 0.19$ & $1.27 \pm 0.24$ & $1.32 \pm 0.43$ & $1.88 \pm 0.38$ & 8 \\
\hline AH6809 & $10 \mu \mathrm{M}$ & $1.12 \pm 0.19$ & $1.14 \pm 0.20$ & $1.42 \pm 0.53$ & $1.23 \pm 0.41$ & 8 \\
\hline L-798106 & $100 \mathrm{nM}$ & $0.97 \pm 0.09$ & $0.82 \pm 0.10$ & $0.68 \pm 0.15$ & $0.80 \pm 0.18$ & 8 \\
\hline AH23848 & $10 \mu \mathrm{M}$ & $0.90 \pm 0.10$ & $0.99 \pm 0.13$ & $1.05 \pm 0.36$ & $1.61 \pm 0.44$ & 12 \\
\hline
\end{tabular}

None of the antagonists had statistically significant effects using a paired Student's two-tailed t-test.

$10 \mu \mathrm{M}$, Table 4). The tissue did not exhibit changes in the tension or in the frequency of phasic contractions in response to the addition of the FP receptor antagonist AL-8810 ( $5 \mu \mathrm{M})$. However, the presence of AL-8810 (5 $\mu \mathrm{M})$ significantly inhibited increases in the baseline tension in response to $\mathrm{PGE}_{2}(10 \mu \mathrm{M}, n=8$, $p<0.05$, Figure 3 ). In the absence of any antagonist, contractions to $\mathrm{PGE}_{2}$ increased the tension by $103 \pm 12 \%$. In the presence of AL-8810 $(5 \mu \mathrm{M})$ this increase was inhibited with the remaining contraction being $77 \pm 8 \%(n=8, p<0.05$, Table 4$)$.

\section{Receptor-Selective Antagonists in Detrusor Preparations}

Detrusor preparations did not reach a visible peak in response to $\mathrm{PGE}_{2}(1 \mu \mathrm{M})$ within the experimental timeframe, so each tension recording was completed at set intervals of 10 and $20 \mathrm{~min}$. As such, changes in detrusor tension were measured at 10 and 20 min after the addition of each agonist (Table 5). The responses to prostaglandin $E_{2}$ were observed in the presence of the selective prostaglandin $\mathrm{E}_{2}$ receptor antagonists: SC-19220 (EP1 antagonist, $10 \mu \mathrm{M})$, AH6809 (EP1/EP2 antagonist, $10 \mu \mathrm{M})$, L798106 (EP3 antagonist, $100 \mathrm{nM}$ ) and AH23848 (EP4 antagonist, $10 \mu \mathrm{M})$. None of the prostaglandin $\mathrm{E}_{2}$ receptor antagonists had any effect on baseline tension in detrusor tissue strips in response to prostaglandin $\mathrm{E}_{2}(1 \mu \mathrm{M})$.

The potential for receptor systems, other than prostaglandin $E_{2}$, to contribute contractile responses to $\mathrm{PGE}_{2}$ were investigated. It was found that the baseline tension in detrusor preparations, in response to prostaglandin $\mathrm{E}_{2}(10 \mu \mathrm{M})$, was not affected by the presence of the muscarinic receptor antagonist atropine
$(1 \mu \mathrm{M})$, cyclooxygenase (COX) inhibitor indomethacin $(5 \mu \mathrm{M})$, nitric oxide synthase inhibitor $\mathrm{N}_{\omega}$-Nitro-L-arginine (L-NNA, $100 \mu \mathrm{M})$ or P2X receptor desensitizing agonist $\alpha, \beta$-methylene ATP ( $\alpha \beta$ m-ATP, $10 \mu \mathrm{M}$, Table 6). Treatment with the FP receptor antagonist AL-8810 (5 $\mu \mathrm{M})$ did not affect baseline responses. In the presence of AL- 8810 increases to baseline tension mediated by prostaglandin $\mathrm{E}_{2}(10 \mu \mathrm{M})$ were significantly inhibited both 10 and 20 min after the addition of the agonist $(n=8, p<0.05$ for both, Figure 4). In the absence of any antagonists, contractions to PGE2 increased the tension by $233 \pm 60 \%$ at $10 \mathrm{~min}$. In the presence of AL-8810 $(5 \mu \mathrm{M})$ this increase was inhibited with the remaining contraction of $127 \pm 46 \%(n=8, p<0.05$, Table 6).

\section{Prostaglandin $\mathbf{F}_{2 \alpha}$ on U\&LP and Detrusor Preparations}

In preparations of U\&LP, treatment with $\mathrm{PGF}_{2 \alpha}(10 \mu \mathrm{M})$ caused a significant increase in the baseline tension of $65 \pm 9 \%(n=14$, $p<0.001)$. Additionally, the frequency of spontaneous phasic contractions increased by $13 \pm 5 \%(n=14, p<0.05)$ with no changes observed in the amplitude of these contractions. In the presence of AL-8810 ( $\mathrm{FP}$ antagonist, $5 \mu \mathrm{M}$ ), increases in the baseline tension in response to $\mathrm{PGF}_{2 \alpha}(10 \mu \mathrm{M})$ were significantly inhibited ( $n=8, p<0.001$, Table 7 and Figure 5). However, the antagonism of FP receptor did not affect the frequency or amplitude of spontaneous phasic contractions.

In detrusor preparations, an increase of $88 \pm 10 \%(n=12$, $p<0.001)$ was observed in response to $\mathrm{PGF}_{2 \alpha}(10 \mu \mathrm{M})$. The presence of FP antagonist AL-8810 $(5 \mu \mathrm{M})$ significantly inhibited increases in the baseline tension $(n=8, p<0.05)$. The inhibition 
TABLE 4 | U\&LP responses to prostaglandin $\mathrm{E}_{2}(10 \mu \mathrm{M})$ in the absence and presence of atropine (muscarinic antagonist), indomethacin (cyclooxygenase antagonist), $\mathrm{N}_{\omega}$-Nitro-L-arginine (L-NNA, nitric oxide antagonist), $\alpha, \beta$-methylene ATP ( $\alpha \beta \mathrm{Bm}$-ATP, ATP agonist), and AL-8810 (FP antagonist) (mean change \pm SEM).

\begin{tabular}{|c|c|c|c|c|c|c|}
\hline Antagonist & Conc. & \multicolumn{2}{|c|}{$\Delta$ Tension $(\mathrm{g})$} & \multicolumn{2}{|c|}{$\Delta$ Frequency (cpm) } & $n$ \\
\hline Indomethacin & $5 \mu \mathrm{M}$ & $1.90 \pm 0.25$ & $1.79 \pm 0.21$ & $0.73 \pm 1.29$ & $2.11 \pm 1.45$ & 4 \\
\hline L-NNA & $100 \mu \mathrm{M}$ & $2.00 \pm 0.32$ & $2.31 \pm 0.42$ & $2.86 \pm 1.32$ & $3.51 \pm 1.78$ & 4 \\
\hline$\alpha \beta m-A T P$ & $10 \mu \mathrm{M}$ & $1.58 \pm 0.35$ & $1.99 \pm 0.48$ & $0.46 \pm 0.22$ & $0.49 \pm 0.23$ & 4 \\
\hline
\end{tabular}

${ }^{*} p<0.05$. Paired Student's two-tailed t-test.

\section{U\&LP}

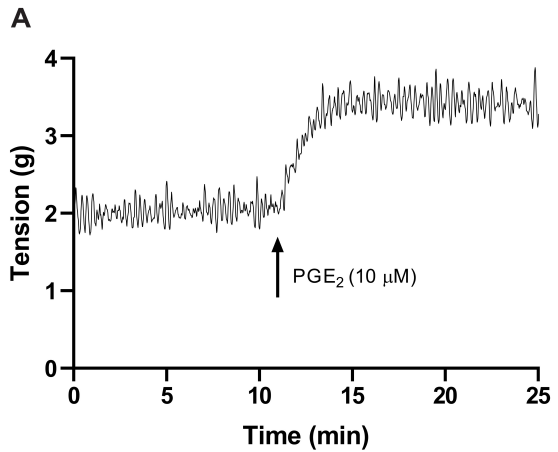

B

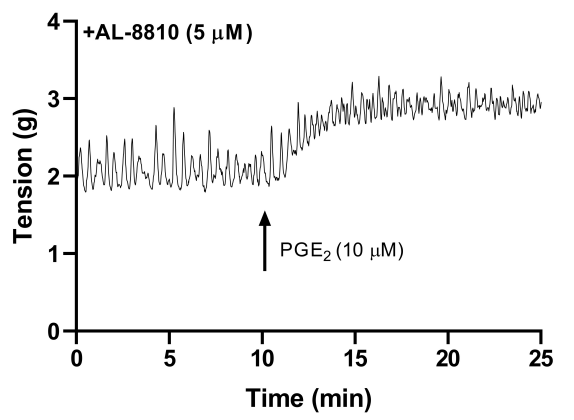

C

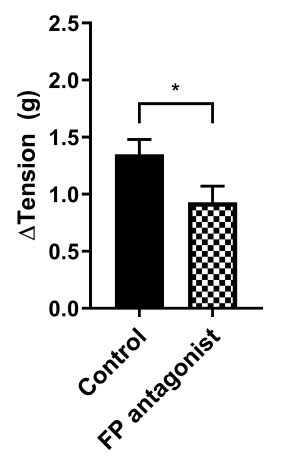

FIGURE 3 | U\&LP responses to $\mathrm{PGE}_{2}(10 \mu \mathrm{M})$ (A) and in the presence of FP receptor antagonist AL-8810 $(5 \mu \mathrm{M})$ (B). Increases in the baseline tension in response to $\mathrm{PGE}_{2}$ are represented as mean change \pm SEM (C). Changes in the baseline tension between control and experimental conditions were evaluated using a paired Student's two tailed $t$-test, where ${ }^{*} p<0.05$.

TABLE 5 | Detrusor responses to prostaglandin $E_{2}(1 \mu \mathrm{M})$ at 10 and 20 min after the addition of agonist in the absence and presence of PGE 2 receptor antagonists (mean change \pm SEM).

$\Delta$ Tension (g) at $10 \mathrm{~min}$

\section{Antagonist}

SC-19220

AH6809

L-798106

AH23848

$10 \mu \mathrm{M}$

Conc.
$10 \mu \mathrm{M}$
$10 \mu \mathrm{M}$
$100 \mathrm{nM}$
$10 \mu \mathrm{M}$

\begin{tabular}{cc}
\hline Absence & Presence \\
$0.60 \pm 0.08$ & $0.49 \pm 0.11$ \\
$0.64 \pm 0.13$ & $0.62 \pm 0.10$ \\
$1.12 \pm 0.20$ & $1.05 \pm 1.16$ \\
$0.46 \pm 0.10$ & $0.49 \pm 0.14$
\end{tabular}

$\Delta$ Tension (g) at $20 \mathrm{~min}$

None of the antagonists had statistically significant effects (paired Student's two-tailed t-test).

TABLE 6 | Detrusor responses to prostaglandin $\mathrm{E}_{2}(10 \mu \mathrm{M})$ in the absence and presence of atropine (muscarinic antagonist), indomethacin (cyclooxygenase antagonist), $N_{\omega}$-Nitro-L-arginine (L-NNA, nitric oxide antagonist), $\alpha, \beta$-methylene ATP ( $\alpha \beta m$-ATP, ATP agonist), and AL-8810 (FP antagonist) (mean change \pm SEM).

\section{$\Delta$ Tension $(\mathrm{g})$ at $10 \mathrm{~min}$}

Antagonist

Atropine

Indomethacin

L-NNA

$\alpha \beta m-A T P$

AL-8810

Conc.
$1 \mu \mathrm{M}$

$5 \mu \mathrm{M}$

$100 \mu \mathrm{M}$

$10 \mu \mathrm{M}$

$5 \mu \mathrm{M}$

$\begin{array}{ll}\text { Absence } \\ \text { M } & 1.38 \pm 0.21 \\ & 1.55 \pm 0.55 \\ 2.21 \pm 0.28 \\ 1.40 \pm 0.21 \\ 1.43 \pm 0.36\end{array}$

\section{$\Delta$ Tension (g) at $20 \mathrm{~min}$}

\begin{tabular}{cc}
\hline Absence & Presence \\
$1.38 \pm 0.21$ & $1.02 \pm 0.09$ \\
$1.55 \pm 0.55$ & $1.29 \pm 0.42$ \\
$2.21 \pm 0.28$ & $1.90 \pm 0.32$ \\
$1.40 \pm 0.21$ & $1.72 \pm 0.49$ \\
$1.43 \pm 0.36$ & $0.84 \pm 0.21^{\star}$
\end{tabular}

$0.21^{\star}$

\begin{tabular}{ccc}
\hline Absence & Presence & $\boldsymbol{n}$ \\
\hline $1.72 \pm 0.11$ & $1.47 \pm 0.11$ & 6 \\
$1.75 \pm 0.55$ & $1.35 \pm 0.43$ & 4 \\
$2.05 \pm 0.26$ & $1.94 \pm 0.27$ & 4 \\
$1.45 \pm 0.29$ & $1.94 \pm 0.43$ & 4 \\
$1.39 \pm 0.22$ & $1.01 \pm 0.18^{*}$ & 8
\end{tabular}

${ }^{*} p<0.05$. Paired Student's two-tailed t-test. 


\section{Detrusor}

A

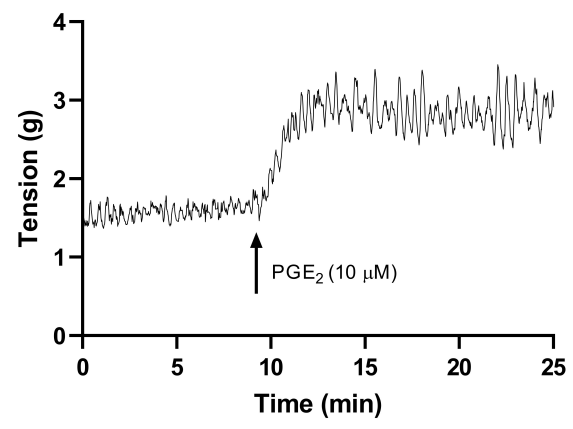

B

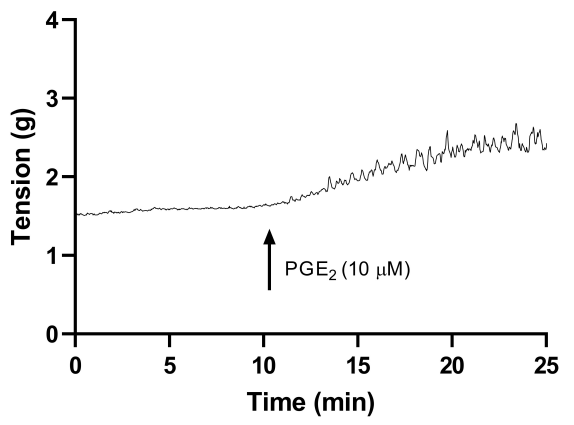

C

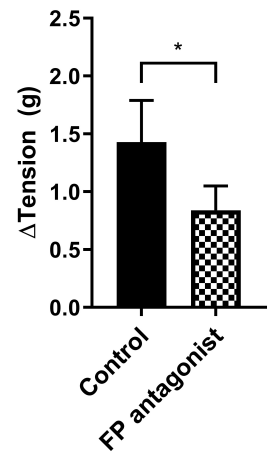

FIGURE 4 | Detrusor responses to $\mathrm{PGE}_{2}(10 \mu \mathrm{M}) \mathbf{( A )}$ and in the presence of FP receptor antagonist $\mathrm{AL}-8810(5 \mu \mathrm{M})$ (B). Increases in the baseline tension in response to $\mathrm{PGE}_{2}$ are represented as mean change $\pm \mathrm{SEM}(\mathbf{C})$. Changes in the baseline tension between control and experimental conditions were evaluated using a paired Student's two tailed $t$-test, where ${ }^{*} p<0.05$.

was maintained both 10 and 20 min after the addition of $\mathrm{PGF}_{2 \alpha}$ (10 $\mu \mathrm{M}$, Table 7).

\section{DISCUSSION}

This study presents prostaglandin $\mathrm{E}_{2}$ as a potential contributor to the overall urinary bladder contractility and showcases the ability of isolated urothelium with lamina propria (also called the bladder mucosa) to respond to this inflammatory mediator. Prostaglandin $\mathrm{E}_{2}$ causes a baseline tension increase in both U\&LP and detrusor tissue, as well as influences the frequency and amplitude of U\&LP spontaneous phasic contractions. In addition, this study is the first to identify responses to $\mathrm{PGE}_{2}$ in the urothelium with lamina propria when separated from its underlying detrusor layer. The two layers are distinct in both structure and function, with the U\&LP comprized of several layers of epithelial cells and an underlying connective tissue layer with muscularis mucosae, while the detrusor is composed primarily of smooth muscle cells. The U\&LP not only provides a physical barrier between urine and the bladder wall but is

TABLE 7 | U\&LP responses to $\mathrm{PGF}_{2 \alpha}(10 \mu \mathrm{M})$ in the absence and presence of $\mathrm{AL}-8810$ on the baseline tension and on the frequency and amplitude of phasic contractions (top).

\begin{tabular}{|c|c|c|c|c|}
\hline & & $\mathrm{PGF}_{2 \alpha}$ & $\begin{array}{c}\text { PGF }_{2 \alpha} \text { with } \\
\text { AL-8810 }\end{array}$ & $n$ \\
\hline \multirow{3}{*}{$\begin{array}{l}\text { Urothelium with } \\
\text { lamina propria } \\
\text { (U\&LP) }\end{array}$} & $\Delta$ Tension $(\mathrm{g})$ & $0.85 \pm 0.09$ & $0.49 \pm 0.08^{\star \star \star}$ & 8 \\
\hline & $\Delta$ Amplitude (g) & $-0.11 \pm 0.06$ & $-0.13 \pm 0.07$ & 8 \\
\hline & $\Delta$ Frequency $(\mathrm{cpm})$ & $0.67 \pm 0.23$ & $0.73 \pm 0.14$ & 8 \\
\hline \multirow[t]{2}{*}{ Detrusor } & $\Delta$ Tension $(\mathrm{g})$ at $10 \mathrm{~min}$ & $0.78 \pm 0.18$ & $0.36 \pm 0.04^{*}$ & 8 \\
\hline & $\Delta$ Tension (g) at $20 \mathrm{~min}$ & $0.91 \pm 0.19$ & $0.57 \pm 0.08$ & 8 \\
\hline
\end{tabular}

Detrusor baseline tension responses at 10 and $20 \mathrm{~min}$ to $P G F_{2 \alpha}(10 \mu \mathrm{M})$ in the absence and presence of AL-8810 (bottom). Results represented as mean change \pm SEM. ${ }^{*} p<0.05,{ }^{* * *} p<0.001$. Paired Student's two-tailed t-test. also capable of releasing chemicals like acetylcholine which can influence the contractility of the detrusor (Moro et al., 2011). Furthermore, it is also capable of responding to external signals like noradrenaline (Moro et al., 2013), nitric oxide (Moro et al., 2012), the five primary prostaglandins (Stromberga et al., 2020b), and histamine (Stromberga et al., 2019, 2020a), as well as release ATP (Andersson et al., 2018). It is known that cells found in U\&LP can express both EP1 and EP2 receptors (Rahnama'i et al., 2010 ) indicating that they are capable of responding to $\mathrm{PGE}_{2}$ and eliciting a contractile response. However, the exact mechanisms and the involvement of the different $\mathrm{PGE}_{2}$ receptor subtypes in the contractile responses observed are still unclear.

In this study, increases in the baseline tension in both U\&LP and detrusor tissues that were treated with two concentrations of $\mathrm{PGE}_{2}(1-10 \mu \mathrm{M})$ were observed. The presence of $\mathrm{PGE}_{2}$ increased the frequency of spontaneous contractile activity, which was similar to responses after muscarinic receptor activation (Moro et al., 2011), the target of many firstline pharmaceuticals to treat overactive bladder. In detrusor preparations, which generally do not exhibit spontaneous phasic contractions, these contractions were initiated in most preparations in response to the addition of $\mathrm{PGE}_{2}$. Previous studies have shown that contractions in detrusor smooth muscle in response to acetylcholine and ATP are enhanced by the presence of prostaglandins in both rabbit (Anderson, 1982) and guinea-pig animal models (Nile and Gillespie, 2012). There are complex interactions between these three molecules, as ATP enhances $\mathrm{PGE}_{2}$ release via a $\mathrm{P} 2$-purinoreceptor-mediated mechanism (Kasakov and Vlaskovska, 1985) and acetylcholine release has been detected when unstretched preparations were exposed to $\mathrm{PGE}_{2}$ (Nile and Gillespie, 2012). Thereby, interactions between these three mediators can potentially result in the amplification of molecule signaling and an increase in contractile activity. However, the involvement of acetylcholine, ATP and nitric oxide in mediating the increases in both the baseline tension and the frequency of spontaneous phasic contractions 


\section{U\&LP}

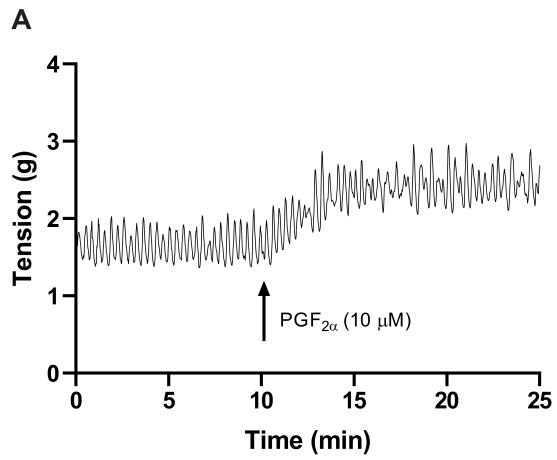

B

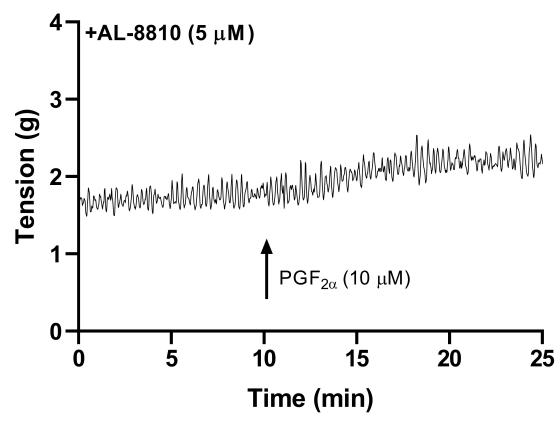

Detrusor

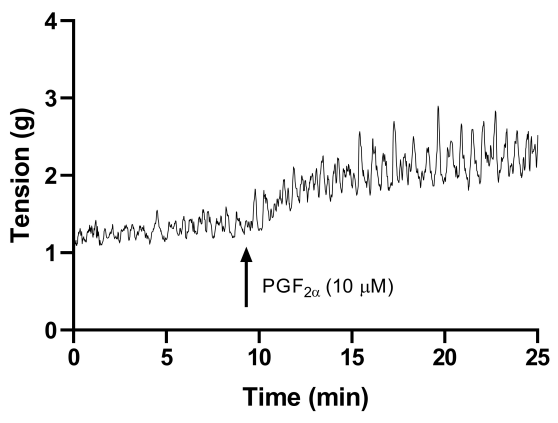

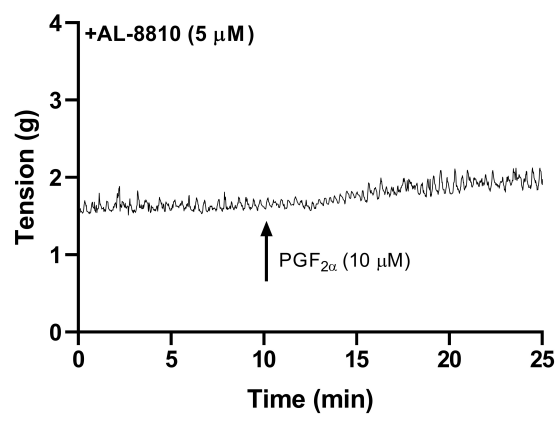

C
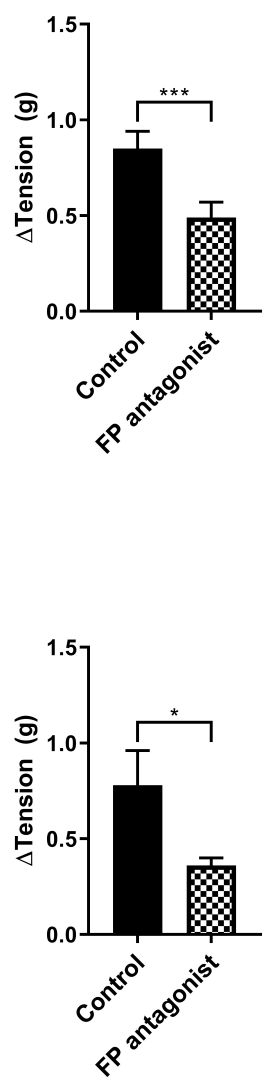

FIGURE 5 | U\&LP and detrusor responses to $\mathrm{PGF}_{2 \alpha}(10 \mu \mathrm{M})$ (A) and in the presence of FP receptor antagonist AL-8810 (5 $\left.\mu \mathrm{M}\right)$ (B). Increases in the baseline tension in response to $\mathrm{PGF}_{2 \alpha}$ are represented as mean change $\pm \mathrm{SEM}$ (C). Changes in the baseline tension between control and experimental conditions were evaluated using a paired Student's two tailed $t$-test, where ${ }^{*} p<0.05,{ }^{* * *} p<0.001$.

were ruled out as the contractile responses were the same when respective receptors were selectively antagonized or desensitized. Therefore, even though previous research has shown that acetylcholine is released when tissue is exposed to $\mathrm{PGE}_{2}$ (Nile and Gillespie, 2012), the inhibition of muscarinic receptors revealed no changes in the magnitude of contractions in response to $\mathrm{PGE}_{2}$. Furthermore, treatment with indomethacin, which inhibits prostaglandin production via cyclooxygenase (COX), did not affect contractile responses.

In order to isolate the role of a specific $\mathrm{PGE}_{2}$ receptor subtype in mediating these changes to baseline tension and the frequency of spontaneous phasic contractions, selective receptor antagonists for EP1-EP4 receptors were used. The antagonists and concentrations selected for this study were based on prior research investigating smooth muscle contractility in rat prostate gland (Tokanovic et al., 2010). When U\&LP and detrusor smooth muscle tissues were treated with each individual $\mathrm{PGE}_{2}$ receptor subtype antagonists (EP1-EP4), there were no differences observed in the contractile responses to $\mathrm{PGE}_{2}$ when compared to tissues with no antagonist treatment. Activation of EP1 and EP3 receptor subtypes mediate contractions in smooth muscle, whereas EP2 and EP4 are involved in the relaxatory responses (Woodward et al., 2011). In this study, when both U\&LP and detrusor tissues were treated with the highly selective EP1 receptor antagonist SC19220 with a $\mathrm{pA}_{2}$ value of approximately 5.9 (Jones et al., 2009) and EP3 receptor antagonist L798106 with a $\mathrm{K} i$ of $0.3 \mathrm{nM}$ (Juteau et al., 2001) there was no change in the magnitude of contractions to $\mathrm{PGE}_{2}$. However, when U\&LP was incubated with the EP1selective receptor antagonist SC-19220, it took significantly more time to reach peak contraction in response to $\mathrm{PGE}_{2}$ compared to control tissues. Even though the stimulation of EP2 receptors has previously been shown to relax nonvascular urogenital smooth muscle tissue (Coleman et al., 1994; Tokanovic et al., 2010), no changes in contractile response were observed in tissue preparations that were treated with the dual EP1 and EP2 antagonist AH6809 [pA for EP1 approximately 7.3 and $\mathrm{pA}_{2}$ for EP2 approximately 5.7 (Jones et al., 2009)]. The involvement of EP4 receptors in the inhibition of muscle contractions was also ruled out using $\mathrm{AH} 23848$, an antagonist for EP4 receptors ( $\mathrm{pA}_{2}$ value 5.4) with no activity on other EP receptor subtypes (Coleman 
et al., 1994). The lack of responses also aligns with previous findings suggesting that the EP4 receptor is involved in vascular smooth muscle relaxation instead of smooth muscle of the urinary bladder (Coleman et al., 1994; Tokanovic et al., 2010). Findings of this study suggest that the contractile responses observed to prostaglandin $\mathrm{E}_{2}$ in both U\&LP and detrusor may be mediated by receptors systems other than EP, purinergic and cholinergic.

The ability of AL-8810 to significantly inhibit the contractile response to $\mathrm{PGE}_{2}$ suggests a mechanism of action at the $\mathrm{FP}$ receptor. This is most likely a result of the $\mathrm{PGE}_{2}$ chemical undergoing a conversion from $\mathrm{PGE}_{2}$ into $\mathrm{PGF}_{2 \alpha}$ through 9-ketoreductase activity upon contact with the tissue. The potential for these conversions has been known for some time (Canete Soler et al., 1987; Cheung and Challis, 1989; Abadir and Siragy, 2015). There is evidence to support a partial agonist effect of AL-8810 (Griffin et al., 1999). Although the addition of this antagonist showed no response, or any effect on the baseline activity. The contraction remaining after FP receptor inhibition is unknown, although does not appear to be related to stimulation of the muscarinic, purinergic or nitric oxide receptor systems, nor from the creation of new prostaglandins. One potential mechanism of action could be via a receptor unspecific pathway, such as affecting calcium channels, and this could be considered for future experiments.

A limitation of this study was the use of single-dose applications of $\mathrm{PGE}_{2}$ and $\mathrm{PGF}_{2 \alpha}$ to examine changes in frequencies and amplitudes of phasic contractions over a 20minute timeframe. It would be of interest to examine a larger range of concentrations, as well as incorporate alternative agonists to obtain a wider understanding of the prostaglandin responses. Finally, there remains no literature showing FP receptor expression or localization in porcine or any other animal model bladders, and its identification throughout this region would assist in a better understanding of this receptor system. It should also be considered that $\mathrm{PGE}_{2}$ exhibits a similar affinity to $\mathrm{PGF}_{2 \alpha}$ on the $\mathrm{FP}$ receptor (Abramovitz et al., 2000), and as such, there is the potential for an influence of FP receptors in the responses observed. This cross-sensitivity of $\mathrm{FP}$ receptors to $\mathrm{PGE}_{2}$ may also present a mechanism underlying the inhibitory effect observed from treatment with AL-8810 and should be further explored in follow-up studies. Future studies could also investigate whether the suppressed responses observed after AL-8810 treatment is due to the actions of $\mathrm{PGE}_{2}$ after a possible conversion to $\mathrm{PGF}_{2 \alpha}$.

This study identifies a functional response in both U\&LP and detrusor preparations to $\mathrm{PGE}_{2}$, and its ability to be inhibited by an FP receptor antagonist suggests some conversion to $\mathrm{PGF}_{2 \alpha}$ upon contact with the tissue. The response of direct application of $\mathrm{PGF}_{2 \alpha}$ which appears to be similar to the $\mathrm{PGE}_{2}$ response also supports this hypothesis. Thereby, the finding of this study supports and further advances prior research, where $\mathrm{PGE}_{2}$ and $\mathrm{PGF}_{2 \alpha}$ had previously been found to contract isolated detrusor smooth muscle in human preparations (Abrams and Feneley, 1975; Andersson et al., 1977; Palea, 1998).

\section{CONCLUSION}

Prostaglandin $\mathrm{E}_{2}$ and prostaglandin $\mathrm{F}_{2 \alpha}$ can elicit clear contractile responses in both urinary bladder urothelium with lamina propria, and detrusor smooth muscle preparations. Furthermore, the addition of these prostaglandins in U\&LP preparations increases the frequency of spontaneous phasic contractions. In the detrusor, which normally does not exhibit spontaneous contractions, these contractions were initiated in most preparations. The antagonism of all four $\mathrm{PGE}_{2}$ receptor subtypes, cholinergic receptors and purinergic receptors failed to inhibit contractile responses observed to the prostaglandins in either U\&LP or detrusor tissues. However, the inhibition of EP1 receptor in U\&LP resulted in a significant decrease in the time taken to reach peak contractile responses to $\mathrm{PGE}_{2}$ suggesting partial mediation via the EP1 receptor system. Antagonism of the FP receptor inhibited responses to $\mathrm{PGF}_{2 \alpha}$, but also to $\mathrm{PGE}_{2}$, suggesting some conversion of this into $\mathrm{PGF}_{2 \alpha}$ after contact with the tissue. Overall, contractile responses to both prostaglandin $\mathrm{E}_{2}$ and prostaglandin $\mathrm{F}_{2 \alpha}$ appear mediated, in part, by the FP receptor in both U\&LP and detrusor smooth muscle.

\section{DATA AVAILABILITY STATEMENT}

The datasets generated for this study are available on request to the corresponding author.

\section{ETHICS STATEMENT}

Ethical review and approval was not required for the animal study because bladders were obtained from the local commercial abattoir after slaughter for the routine commercial provision of food. As no animals were bred, harmed, culled, interfered, or interacted with as part of this research project, Animal Ethics Approval was not required for bladder use (reference cited in section “Tissue Preparation”).

\section{AUTHOR CONTRIBUTIONS}

ZS collected the data. All authors were all equally responsible for the study design, data analysis, preparation of manuscript, approved the final manuscript, and are accountable for all aspects of the work. All persons designated as authors qualify for authorship, and all those who qualify for authorship are listed.

\section{FUNDING}

This research was supported by the Australian Bladder Foundation managed by the Continence Foundation of Australia. ZS was supported by an Australian Government Research Training Program Scholarship. 


\section{REFERENCES}

Abadir, P. M., and Siragy, H. M. (2015). Angiotensin type 1 receptor mediates renal production and conversion of prostaglandins E2 to F2 $\alpha$ in conscious diabetic rats. J. Renin. Angiotensin. Aldosterone Syst. 16, 774-779. doi: 10.1177/ 1470320315592566

Abramovitz, M., Adam, M., Boie, Y., Carriere, M., Denis, D., Godbout, C., et al. (2000). The utilization of recombinant prostanoid receptors to determine the affinities and selectivities of prostaglandins and related analogs. Biochim. Biophys. Acta 1483, 285-293. doi: 10.1016/s1388-1981(99)00164-x

Abrams, P. H., and Feneley, R. C. (1975). The actions of prostaglandins on the smooth muscle of the human urinary tract in vitro. Br. J. Urol. 47, 909-915. doi: 10.1111/j.1464-410x.1975.tb04075.x

Abrams, P. H., Sykes, J. A., Rose, A. J., and Rogers, A. F. (1979). The synthesis and release of prostaglandins by human urinary bladder muscle in vitro. Invest Urol. $16,346-348$.

Anderson, G. F. (1982). Evidence for a prostaglandin link in the purinergic activation of rabbit bladder smooth muscle. J. Pharmacol. Exp. Ther. 220, $347-352$.

Andersson, K. E. (2010). Detrusor myocyte activity and afferent signaling. Neurourol. Urodyn. 29, 97-106. doi: 10.1002/nau.20784

Andersson, K. E., Ek, A., and Persson, C. G. (1977). Effects of prostaglandins on the isolated human bladder and urethra. Acta Physiol. Scand. 100, 165-171. doi: 10.1111/j.1748-1716.1977.tb05933.x

Andersson, K. E., Fry, C., Panicker, J., and Rademakers, K. (2018). Which molecular targets do we need to focus on to improve lower urinary tract dysfunction? ICI-RS 2017. Neurourol. Urodyn. 37, S117-S126.

Birder, L. A. (2006). Urinary bladder urothelium: molecular sensors of chemical/thermal/mechanical stimuli. Vascul Pharmacol 45, 221-226. doi: 10. 1016/j.vph.2005.08.027

Bultitude, M. I., Hills, N. H., and Shuttleworth, K. E. D. (1976). Clinical and experimental studies on the action of prostaglandins and their synthesis inhibitors on detrusor muscle in vitro and in vivo. Br. J. Urol. 48, 631-637. doi: 10.1111/j.1464-410x.1976.tb06711.x

Canete Soler, R., Lopez Bernal, A., and Turnbull, A. C. (1987). Conversion of prostaglandin E2 to prostaglandin F2 alpha by human myometrium. Horm. Metab. Res. 19, 515-516. doi: 10.1055/s-2007-1011871

Cheng, Y., Mansfield, K., Sandow, S., Sadananda, P., Burcher, E., and Moore, K. (2011). Porcine bladder urothelial, myofibroblast, and detrusor muscle cells: characterization and ATP release. Front. Pharmacol. 2:27 doi: 10.3389/fphar. 2011.00027

Cheung, P. Y., and Challis, J. R. (1989). Prostaglandin E2 metabolism in the human fetal membranes. Am. J. Obstet. Gynecol. 161, 1580-1585. doi: 10.1016/00029378(89)90930-7

Chuang, Y. C., Tyagi, P., Huang, C. C., Chancellor, M. B., and Yoshimura, N. (2012). Mechanisms and urodynamic effects of a potent and selective EP4 receptor antagonist, MF191, on cyclophosphamide and prostaglandin E2induced bladder overactivity in rats. BJU Int. 110, 1558-1564. doi: 10.1111/j. 1464-410x.2012.11096.x

Clark, J. D., Lin, L. L., Kriz, R. W., Ramesha, C. S., Sultzman, L. A., Lin, A. Y., et al. (1991). A novel arachidonic acid-selective cytosolic PLA2 contains a $\mathrm{Ca}(2+)$ dependent translocation domain with homology to PKC and GAP. Cell 65, 1043-1051. doi: 10.1016/0092-8674(91)90556-e

Coleman, R. A., Smith, W. L., and Narumiya, S. (1994). International Union of Pharmacology classification of prostanoid receptors: properties, distribution, and structure of the receptors and their subtypes. Pharmacol. Rev. 46, 205-229.

D'ancona, C., Haylen, B., Oelke, M., Abranches-Monteiro, L., Arnold, E., Goldman, H., et al. (2019). The international continence society (ICS) report on the terminology for adult male lower urinary tract and pelvic floor symptoms and dysfunction. Neurourol. Urodyn. 38, 433-477. doi: 10.1002/nau.23897

De Groat, W. C., Nadelhaft, I., Milne, R. J., Booth, A. M., Morgan, C., and Thor, K. (1981). Organization of the sacral parasympathetic reflex pathways to the urinary bladder and large intestine. J. Auton. Nerv. Syst. 3, 135-160. doi: $10.1016 / 0165-1838(81) 90059-\mathrm{x}$

De Jongh, R. (2007). The effects of exogenous prostaglandins and the identification of constitutive cyclooxygenase I and II immunoreactivity in the normal guinea pig bladder. BJU Int. 100, 419-429. doi: 10.1111/j.1464-410x.2007.07011.x
De Jongh, R. (2009). The localization of cyclo-oxygenase immuno-reactivity (COX I-IR) to the urothelium and to interstitial cells in the bladder wall. J. Cell. Mol. Med. 13, 3069-3081. doi: 10.1111/j.1582-4934.2008.00475.x

Ferguson, D. R., Kennedy, I., and Burton, T. J. (1997). ATP is released from rabbit urinary bladder epithelial cells by hydrostatic pressure changes-a possible sensory mechanism? J. Physiol. 505(Pt 2), 503-511. doi: 10.1111/j.1469-7793. 1997.503bb.x

Fry, C. H., Sui, G. P., Kanai, A. J., and Wu, C. (2007). The function of suburothelial myofibroblasts in the bladder. Neurourol. Urodyn. 26, 914-919. doi: 10.1002/ nau. 20483

Fry, C. H., and Vahabi, B. (2016). The role of the mucosa in normal and abnormal bladder function. Basic Clin. Pharmacol. Toxicol. 119(Suppl. 3), 57-62. doi: $10.1111 /$ bcpt.12626

Funk, C. D. (2001). Prostaglandins and leukotrienes: advances in eicosanoid biology. Science 294, 1871-1875. doi: 10.1126/science.294.5548.1871

Griffin, B. W., Klimko, P., Crider, J. Y., and Sharif, N. A. (1999). AL-8810: a novel prostaglandin F2 alpha analog with selective antagonist effects at the prostaglandin F2 alpha (FP) receptor. J. Pharmacol. Exp. Ther. 290, 1278-1284.

Haylen, B. T., De Ridder, D., Freeman, R. M., Swift, S. E., Berghmans, B., Lee, J., et al. (2010). An international urogynecological association (iuga)/international continence society (ICS) joint report on the terminology for female pelvic floor dysfunction. Neurourol. Urodyna. 29, 4-20.

Hegde, S. S., Choppin, A., Bonhaus, D., Briaud, S., Loeb, M., Moy, T. M., et al. (1997). Functional role of M2 and M3 muscarinic receptors in the urinary bladder of rats in vitro and in vivo. Br. J. Pharmacol. 120, 1409-1418.

Jeremy, J. Y., Mikhailidis, D. P., and Dandona, P. (1984). The rat urinary bladder produces prostacyclin as well as other prostaglandins. Prostaglandins Leukot. Med. 16, 235-248.

Jeremy, J. Y., Tsang, V., Mikhailidis, D. P., Rogers, H., Morgan, R. J., and Dandona, P. (1987). Eicosanoid synthesis by human urinary bladder mucosa: pathological implications. Br. J. Urol. 59, 36-39. doi: 10.1111/j.1464-410x.1987.tb04575.x

Jones, R. L., Giembycz, M. A., and Woodward, D. F. (2009). Prostanoid receptor antagonists: development strategies and therapeutic applications. $\mathrm{Br}$. J. Pharmacol. 158, 104-145. doi: 10.1111/j.1476-5381.2009.00317.x

Juteau, H., Gareau, Y., Labelle, M., Sturino, C. F., Sawyer, N., Tremblay, N., et al. (2001). Structure-activity relationship of cinnamic acylsulfonamide analogues on the human EP3 prostanoid receptor. Bioorg. Med. Chem. 9, 1977-1984. doi: 10.1016/s0968-0896(01)00110-9

Kasakov, L. N., and Vlaskovska, M. V. (1985). Profile of prostaglandins generated in the detrusor muscle of rat urinary bladder: effects of adenosine triphosphate and adenosine. Eur. J. Pharmacol. 113, 431-436. doi: 10.1016/0014-2999(85) 90092-5

Kim, J. C., Park, E. Y., Seo, S. I., Park, Y. H., and Hwang, T.-K. (2006). Nerve growth factor and prostaglandins in the urine of female patients with overactive bladder. J. Urol. 175, 1773-1776. doi: 10.1016/s0022-5347(05)00992-4

Leslie, C. A., Pavlakis, A. J., Wheeler, J. S., Siroky, M. B., and Krane, R. J. (1984). Release of arachidonate cascade products by the rabbit bladder: neurophysiological significance? J. Urol. 132, 376-379. doi: 10.1016/s00225347(17)49631-5

Maggi, C. A. (1988). Prostanoids modulate reflex micturition by acting through capsaicin-sensitive afferents. Eur. J. Pharmacol. 145, 105-112. doi: 10.1016/ 0014-2999(88)90221-x

Masick, J. M., Levin, R. M., and Hass, M. A. (2001). The effect of partial outlet obstruction on prostaglandin generation in the rabbit urinary bladder. Prostaglandins Other Lipid Mediat. 66, 211-219. doi: 10.1016/s0090-6980(01) 00151-4

Masunaga, K., Yoshida, M., Inadome, A., Iwashita, H., Miyamae, K., and Ueda, S. (2006). Prostaglandin E2 release from isolated bladder strips in rats with spinal cord injury. Int. J. Urol. 13, 271-276. doi: 10.1111/j.1442-2042.2006.01274.x

Mccafferty, G. P., Misajet, B. A., Laping, N. J., Edwards, R. M., and Thorneloe, K. S. (2008). Enhanced bladder capacity and reduced prostaglandin E2-mediated bladder hyperactivity in EP3 receptor knockout mice. Am. J. Physiol. Renal Physiol. 295, F507-F514.

Milsom, I., Kaplan, S. A., Coyne, K. S., Sexton, C. C., and Kopp, Z. S. (2012). Effect of bothersome overactive bladder symptoms on health-related quality of life, anxiety, depression, and treatment seeking in the United States: results from EpiLUTS. Urology 80, 90-96. doi: 10.1016/j.urology.2012.04.004 
Mitsui, R., Lee, K., Uchiyama, A., Hayakawa, S., Kinoshita, F., Kajioka, S., et al. (2019). Contractile elements and their sympathetic regulations in the pig urinary bladder: a species and regional comparative study. Cell Tissue Res. 379, 373-387. doi: 10.1007/s00441-019-03088-6

Moro, C., Leeds, C., and Chess-Williams, R. (2012). Contractile activity of the bladder urothelium/lamina propria and its regulation by nitric oxide. Eur. J. Pharmacol. 674, 445-449. doi: 10.1016/j.ejphar.2011.11.020

Moro, C., Tajouri, L., and Chess-Williams, R. (2013). Adrenoceptor function and expression in bladder urothelium and lamina propria. Urology 81:211.e1-e7.

Moro, C., Uchiyama, J., and Chess-Williams, R. (2011). Urothelial/lamina propria spontaneous activity and the role of $\mathrm{M} 3$ muscarinic receptors in mediating rate responses to stretch and carbachol. Urology 78:1442.e9-e15.

Nile, C. J., De Vente, J., and Gillespie, J. I. (2010). Stretch independent regulation of prostaglandin E2 production within the isolated guinea-pig lamina propria. BJU Int. 105, 540-548. doi: 10.1111/j.1464-410x.2009.08705.x

Nile, C. J., and Gillespie, J. I. (2012). Interactions between cholinergic and prostaglandin signaling elements in the urothelium: role for muscarinic type 2 receptors. Urology 79:240.e17-e23.

Palea, S. (1998). Pharmacological characterization of thromboxane and prostanoid receptors in human isolated urinary bladder. Br. J. Pharmacol. 124, 865-872. doi: 10.1038/sj.bjp.0701903

Park, J. M., Yang, T., Arend, L. J., Schnermann, J. B., Peters, C. A., Freeman, M. R., et al. (1999). Obstruction stimulates COX-2 expression in bladder smooth muscle cells via increased mechanical stretch. Am. J. Physiol. 276, F129-F136.

Parsons, B. A., Drake, M. J., Gammie, A., Fry, C. H., and Vahabi, B. (2012). The validation of a functional, isolated pig bladder model for physiological experimentation. Front. Pharmacol. 3:52.

Ponglowhapan, S., Church, D. B., and Khalid, M. (2010). Expression of prostaglandin $\mathrm{E}(2)$ receptor subtypes in the canine lower urinary tract varies according to the gonadal status and gender. Theriogenology 74, 1450-1466. doi: 10.1016/j.theriogenology.2010.06.017

Queensland Government (2016). Using Animals in Science. Available: https://www.business.qld.gov.au/industries/farms-fishing-forestry/agriculture/ livestock/animal-welfare/animals-science/activities/dead-animals (accessed October 30, 2019).

Rahnama'i, M. S., Van Koeveringe, G. A., Essers, P. B., De Wachter, S. G., De Vente, J., Van Kerrebroeck, P. E., et al. (2010). Prostaglandin receptor EP1 and EP2 site in guinea pig bladder urothelium and lamina propria. J. Urol. 183, 1241-1247. doi: $10.1016 /$ j.juro.2009.11.004

Reyes, A. A., and Klahr, S. (1990). Bladder contributes to eicosanoids excreted in urine. Am. J. Physiol. 259, F859-F861.

Root, J. A., Davey, D. A., and Af Forselles, K. J. (2015). Prostanoid receptors mediating contraction in rat, macaque and human bladder smooth muscle in vitro. Eur. J. Pharmacol. 769, 274-279. doi: 10.1016/j.ejphar.2015. 11.030

Schmauder-Chock, E. A., and Chock, S. P. (1989). Localization of cyclo-oxygenase and prostaglandin E2 in the secretory granule of the mast cell. J. Histochem. Cytochem. 37, 1319-1328. doi: 10.1177/37.9.2504812
Schroder, A., Newgreen, D., and Andersson, K. E. (2004). Detrusor responses to prostaglandin E2 and bladder outlet obstruction in wildtype and Ep1 receptor knockout mice. J. Urol. 172, 1166-1170. doi: 10.1097/01.ju.0000134186.58854.2c

Sigala, S., Mirabella, G., Peroni, A., Pezzotti, G., Simeone, C., Spano, P., et al. (2002). Differential gene expression of cholinergic muscarinic receptor subtypes in male and female normal human urinary bladder. Urology 60, 719-725. doi: 10.1016/s0090-4295(02)01819-8

Stephenson, M. L., and Wing, D. A. (2015). A novel misoprostol delivery system for induction of labor: clinical utility and patient considerations. Drug Des Dev.Ther. 9, 2321-2327.

Stromberga, Z., Chess-Williams, R., and Moro, C. (2019). Histamine modulation of urinary bladder urothelium, lamina propria and detrusor contractile activity via $\mathrm{H} 1$ and $\mathrm{H} 2$ receptors. Sci. Rep. 9:3899.

Stromberga, Z., Chess-Williams, R., and Moro, C. (2020a). Alterations in histamine responses between juvenile and adult urinary bladder urothelium, lamina propria and detrusor tissues. Sci. Rep. 10:4116.

Stromberga, Z., Chess-Williams, R., and Moro, C. (2020b). The five primary prostaglandins stimulate contractions and phasic activity of the urinary bladder urothelium, lamina propria and detrusor. BMC Urol. 20:48. doi: 10.1186/ s12894-020-00619-0

Sunil Kumar, K. S., Shyam, S., and Batakurki, P. (2016). Carboprost versus oxytocin for active management of third stage of labor: a prospective randomized control study. J. Obstetr. Gynaecol. India 66, 229-234. doi: 10.1007/s13224-016-0842-x

Tokanovic, S., White, C. W., Malone, D. T., Exintaris, B., and Ventura, S. (2010). Characterisation of the prostanoid receptor mediating inhibition of smooth muscle contractility in the rat prostate gland. Naunyn Schmiedebergs Arch. Pharmacol. 381, 321-328. doi: 10.1007/s00210-010-0492-y

Wheeler, M. A., Yoon, J. H., Olsson, L. E., and Weiss, R. M. (2001). Cyclooxygenase-2 protein and prostaglandin $\mathrm{E}(2)$ production are up-regulated in a rat bladder inflammation model. Eur. J. Pharmacol. 417, 239-248. doi: 10.1016/s0014-2999(01)00911-6

Woodward, D. F., Jones, R. L., and Narumiya, S. (2011). International union of basic and clinical pharmacology. LXXXIII: classification of prostanoid receptors, updating 15 years of progress. Pharmacol. Rev. 63, 471-538. doi: $10.1124 /$ pr. 110.003517

Conflict of Interest: The authors declare that the research was conducted in the absence of any commercial or financial relationships that could be construed as a potential conflict of interest.

Copyright (c) 2020 Stromberga, Chess-Williams and Moro. This is an open-access article distributed under the terms of the Creative Commons Attribution License (CC BY). The use, distribution or reproduction in other forums is permitted, provided the original author(s) and the copyright owner(s) are credited and that the original publication in this journal is cited, in accordance with accepted academic practice. No use, distribution or reproduction is permitted which does not comply with these terms. 